\title{
Overview of the Mark Twain Lake/ Salt River Basin Conservation Effects Assessment Project
}

\author{
R.N. Lerch, E.J. Sadler, N.R. Kitchen, K.A. Sudduth, R.J. Kremer, D.B. Myers, C. Baffaut, \\ S.H. Anderson, and C.-H. Lin
}

\begin{abstract}
The Mark Twain Lake/Salt River Basin was selected as one of the USDA Agricultural Research Service benchmark watersheds for the Conservation Effects Assessment Project because of documented soil and water quality problems and broad stakeholder interest. The basin is located in northeastern Missouri within the Central Claypan Region, and it is the source of water to Mark Twain Lake, the major public water supply in the region. At the outlet to Mark Twain Lake, the basin drains $6,417 \mathrm{~km}^{2}\left(2,478 \mathrm{mi}^{2}\right)$, including 10 major watersheds that range in area from 271 to $1,579 \mathrm{~km}^{2}$ (105 to $\left.609 \mathrm{mi}^{2}\right)$. The basin is characterized by flat to gently rolling topography with a predominance of claypan soils that result in high runoff potential. The claypan soils are especially vulnerable to soil erosion, which has degraded soil and water quality throughout the basin, and to surface transport of herbicides. Results from cropping system best management practice studies showed that no-till cropping systems did not reduce surface runoff compared to tilled systems, and no-till led to increased transport of soil-applied herbicides. A major challenge is the need to develop cropping systems that incorporate herbicides yet maintain sufficient crop residue cover to control soil erosion. Results of the Soil and Water Assessment Tool model simulations showed that the model was capable of simulating observed long-term trends in atrazine concentrations and loads and the impact of grass waterways on atrazine concentrations. Current and future research efforts will continue to focus on best management practice studies, development of needed tools to improve watershed management, and refinements in the calibration and validation of the Soil and Water Assessment Tool model.
\end{abstract}

Key words: Conservation Effects Assessment Project (CEAP)—claypan soils-cropping systems — simulation modeling-water quality monitoring-watershed management

The Salt River Basin in northeastern Missouri was selected as one of the USDA Agricultural Research Service benchmark watersheds for the Conservation Effects Assessment Project (CEAP). The basin is the source of water to Mark Twain Lake, a 7,533-ha (18,614-ac) US Army Corps of Engineers reservoir that is the major public water supply in the region (figure 1). The Mark Twain Lake/Salt River Basin was selected as a CEAP research area because of broad stakeholder interest and documented soil and water quality problems. The basin encompasses the heart of the Central Claypan Region major land resource area (MLRA 113) (USDA Natural Resources Conservation Service [NRCS] 2006). The fied. This represents the primary rationale for the development of CEAP, which is to quantify the environmental benefits of these conservation programs. The specific objectives of the Mark Twain Lake/Salt River Basin CEAP encompass three of the five objectives contained in the national CEAP plan (i.e., database development, evaluation of best management practices [BMPs], and computer modeling of contaminant transport), with detailed research objectives tailored to the Salt River Basin. Anticipated products of this research include establishment of the publicly available Sustaining the Earth's Watersheds-Agricultural Research Data System (STEWARDS), knowledge of the watersheds contributing the highest contaminant loads to Mark Twain Lake, and guidelines for implementing BMPs and targeting conservation practices. However, the specific objective of this article is to provide a context for the Mark Twain Lake/Salt River Basin CEAP, including the physical and historical setting, primary conservation concerns, legacy data and environmental infrastructure, research and modeling results, and needed tools for improving watershed management.

\section{Salt River Basin}

Physiographic Region, Topography, and Predominant Soils. The Salt River Basin drains a major portion of Northeast Missouri into the Mississippi River. The basin is located within the Dissected Till Plains Physiographic Region (12e) (Fenneman and Johnson 1946) and is contained primarily within MLRA 113. Elevation in the watershed varies from $305 \mathrm{~m}(1,000 \mathrm{ft})$ above mean sea level to $158 \mathrm{~m}(518 \mathrm{ft})$ above mean

naturally formed claypan represents the key hydrologic feature of the basin, and it is the direct cause of the high runoff potential of these soils. Land use is predominately agricultural within the basin. The primary rowcrops are soybean (Glycine max), corn (Zea mays), wheat (Triticum aestivum), and sorghum (Sorghum bicolor). Forage production is mainly tall fescue (Festuca arundinacea). Livestock production is mainly beef cattle, but swine operations are increasing.

While it is widely recognized that the conservation programs funded by the Farm Security and Rural Investment Act of 2002 - referred to as the 2002 farm bill — can protect millions of acres, the environmental benefits have not previously been quanti-
Robert N. Lerch, E. John Sadler, and Newell R. Kitchen are soil scientists, Kenneth A. Sudduth is an agricultural engineer, and Robert J. Kremer is a microbiologist at the Cropping Systems and Water Quality Research Unit, USDA Agricultural Research Service (ARS), Columbia, Missouri. D. Brenton Myers is a graduate research assistant in the Department of Soil, Environmental and Atmospheric Sciences, University of Missouri, Columbia, Missouri. Claire Baffaut is a hydrologist at the Cropping Systems and Water Quality Research Unit, USDA ARS, Columbia, Missouri. Stephen H. Anderson is a professor in the Department of Soil, Environmental and Atmospheric Sciences, University of Missouri, Columbia, Missouri. Chung-Ho Lin is a research assistant professor in the Department of Forestry, University of Missouri, Columbia, Missouri. 


\section{Figure 1}

Watersheds of the Salt River Basin.

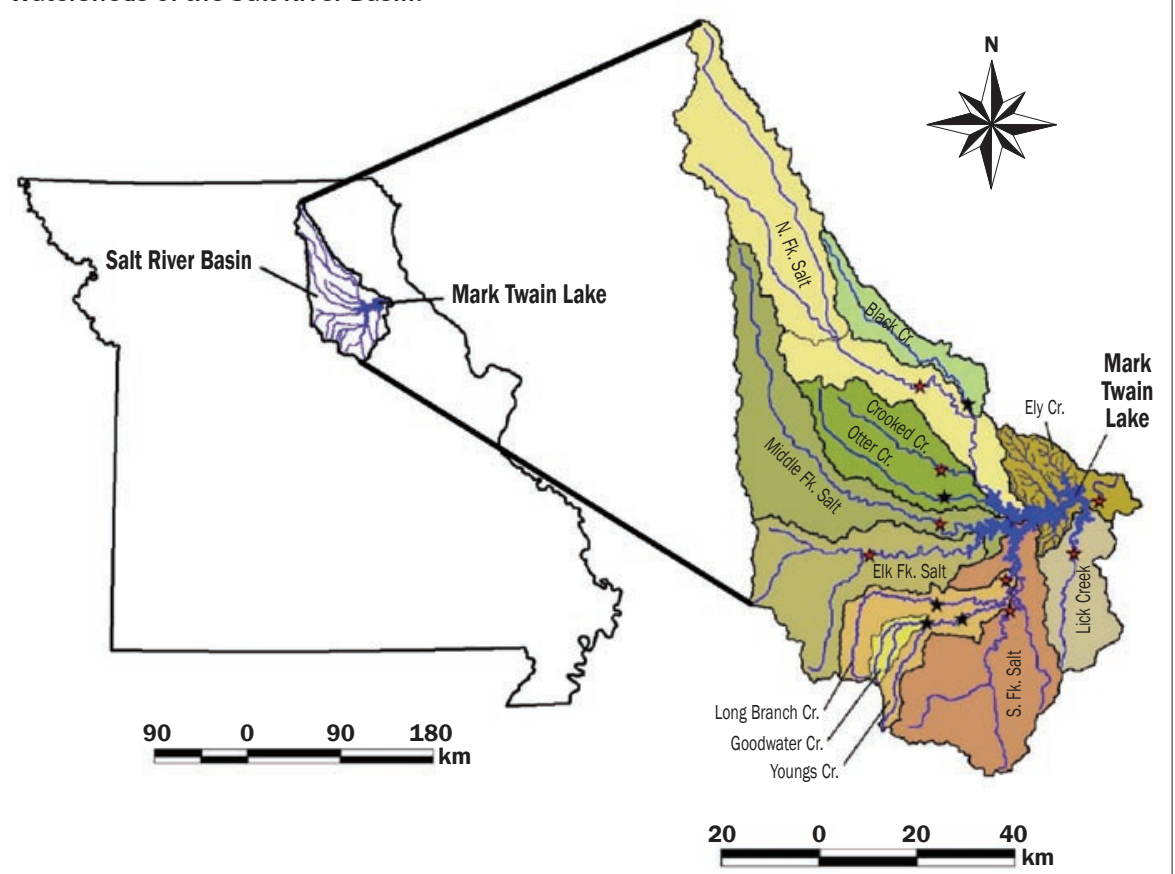

Notes: Red stars indicate monitoring stations operated by the US Geological Survey. Black stars indicate monitoring stations operated by USDA Agricultural Research Service or their cooperators. Watershed colors are included to more easily distinguish between the watersheds.

sea level just below the outlet of Mark Twain Lake, about $100 \mathrm{~km}$ (62.1 mi) upstream from the mouth of the Salt River. The topography of the Salt River Basin is flat and gently rolling in its upper reaches ( $0 \%$ to $2 \%$ slope on ridges, $3 \%$ to $7 \%$ on backslopes) but becomes steeply rolling and deeply dissected near the major tributaries (2\% to $5 \%$ slope on ridges, $5 \%$ to $20 \%$ on backslopes).

Claypan soils are predominant in the Salt River Basin. These soils are characterized by a subsoil horizon with an abrupt and large increase in clay content within a short vertical distance in the soil profile (Soil Science Society of America 2001). The Midwestern US claypan region encompasses an area of about $4 \times 10^{6}$ ha within Missouri, Illinois, and Kansas (Jamison et al. 1968; Anderson et al. 1990). The claypan depth varies from 0.1 to $0.5 \mathrm{~m}$ (0.3 to $1.6 \mathrm{ft})$ with clay content ranging from 350 to $600 \mathrm{~g} \mathrm{~kg}^{-1}$ (35\% to 60\%) (Miles and Hammer 1989; Blanco-Canqui et al. 2002; USDA NRCS 2006). Smectite clay minerals with high shrink-swell potential dominate the argillic zone. During the winter and spring periods, the clays are swollen, and their low saturated hydraulic conductivity impedes infiltration and perches water above the claypan, causing a high prob- ability of runoff (Blanco-Canqui et al. 2002). There is also a high probability of annual shrinkage cracks forming during the late summer and early fall periods. Preferential flow through these cracks is significant (Baer and Anderson 1997).

State Soil Geographic (STATSGO) database soils for the Salt River Basin are provided in table 1. The claypan soils in the basin include the Armstrong, Edina, Mexico, and Putnam series which cover $68 \%$ of the land area. Other soil series include the Lindley series, which covers $22 \%$ of the basin, is well drained and moderately permeable, and forms in dissected glacial till that may have a thin loess cap; and the Fatima series, which is $6.4 \%$ of the basin, is moderately well drained with moderate permeability, and forms in alluvium. The remaining soils each have less than $1 \%$ extent. All of the subbasins include a predominance of claypan soils except the Middle Fork subbasin which is dominated by the Lindley series (56\%) (table 1).

Most soils in the basin are classified in hydrologic groups C and D (USDA NRCS 2005b). Group C soils are primarily hillslope soils in dissected till. They have a slow infiltration rate and moderate runoff potential due to argillic horizons or paleosols that impede downward movement of water. Group D soils occurring at summits have a very slow infiltration rate and high runoff potential due to claypans, as described above. Group D soils formed in alluvium have a seasonally high water table and/or high flooding potential.

Watershed Hydrology. The Salt River Basin drains $6,417 \mathrm{~km}^{2}\left(2,478 \mathrm{mi}^{2}\right)$ at the outlet to Mark Twain Lake, and the basin is comprised of 10 watersheds designated as 11-digit hydrologic units by the US Geological Survey (USGS) (Seaber et al. 1987) (figure 1). Drainage areas of the watersheds range in size from 27,070 to 157,910 ha $(66,900$ to 390,210 ac) (table 1$)$. The major watersheds are the primary forks of the Salt River, including the North, Middle, Elk, and South Forks, and these four watersheds account for $67 \%$ of the basin's drainage area (as depicted in figure 1). The remainder of the drainage area is comprised of several smaller watersheds including Black Creek, Crooked Creek, Otter Creek, Long Branch Creek, Lick Creek, and Ely Creek. The Ely Creek 11-digit watershed delineation includes many small tributaries draining directly to Mark Twain Lake, and it also includes about $28 \mathrm{~km}^{2}\left(11 \mathrm{mi}^{2}\right)$ that are inundated by the lake.

Stream orders within the basin were determined from 7.5-minute USGS topographic maps by the Missouri Department of Conservation (2004). There are 165 third order and larger streams in the entire basin, and the main stem of the Salt River is a seventh order stream below the dam. All the larger scale watershed streams included in the monitoring network (see Experimental Infrastructure and Legacy Data section below) are fourth and fifth order streams, except the North Fork, which is a sixth order stream (figure 1). Channel gradients for the major streams in the upper Salt River Basin are rather low (Missouri Department of Conservation 2004). Of the fifth order and larger streams in the basin, gradients range from $0.7 \mathrm{~m} \mathrm{~km}^{-1}\left(3.7 \mathrm{ft} \mathrm{mi}^{-1}\right)$ for the Salt River below the dam to $2.7 \mathrm{~m} \mathrm{~km}^{-1}(14.3 \mathrm{ft}$ $\mathrm{mi}^{-1}$ ) in Bear Creek (a North Fork subwatershed). Although the higher order streams have low gradients, many third order streams in the upper portions of these watersheds have gradients ranging from 7 to $24 \mathrm{~m} \mathrm{~km}^{-1}$ (37 to $127 \mathrm{ft} \mathrm{mi}^{-1}$ ). Average annual precipitation since 2000 at four weather stations located within or near the basin (Agricultural Electronic Bulletin Board 2007) ranged from 
Table 1

Land use and soil types for the Salt River Basin and its major watersheds.

\begin{tabular}{|c|c|c|c|c|c|c|c|c|c|c|c|}
\hline & $\begin{array}{l}\text { Salt River } \\
\text { Basin } \\
\end{array}$ & $\begin{array}{l}\text { Black } \\
\text { Creek }\end{array}$ & $\begin{array}{l}\text { Crooked } \\
\text { Creek }\end{array}$ & $\begin{array}{l}\text { Elk } \\
\text { Fork } \\
\end{array}$ & $\begin{array}{l}\text { Ely } \\
\text { Creek }\end{array}$ & $\begin{array}{l}\text { Lick } \\
\text { Creek }\end{array}$ & $\begin{array}{l}\text { Long } \\
\text { Branch } \\
\end{array}$ & $\begin{array}{l}\text { Middle } \\
\text { Fork } \\
\end{array}$ & $\begin{array}{l}\text { North } \\
\text { Fork }\end{array}$ & $\begin{array}{l}\text { Otter } \\
\text { Creek }\end{array}$ & $\begin{array}{l}\text { South } \\
\text { Fork }\end{array}$ \\
\hline Area (ha) & 591,770 & 27,630 & 28,410 & 72,360 & 27,950 & 35,000 & 46,930 & 88,310 & 157,910 & 27,070 & 80,200 \\
\hline Percent of Salt River Basin & $100 \%$ & $4.7 \%$ & $4.8 \%$ & $12.2 \%$ & $4.7 \%$ & $5.9 \%$ & $7.9 \%$ & $14.9 \%$ & $26.7 \%$ & $4.6 \%$ & $13.6 \%$ \\
\hline \multicolumn{12}{|l|}{ Land use } \\
\hline Pasture & $32.9 \%$ & $24.3 \%$ & $26.5 \%$ & $38.6 \%$ & $25.6 \%$ & $17.2 \%$ & $18.5 \%$ & $43.4 \%$ & $41.0 \%$ & $20.3 \%$ & $27.6 \%$ \\
\hline Water & $2.5 \%$ & $0.5 \%$ & $0.4 \%$ & $1.6 \%$ & $14.1 \%$ & $1.7 \%$ & $1.0 \%$ & $1.3 \%$ & $3.3 \%$ & $1.1 \%$ & $1.9 \%$ \\
\hline Forest & $18.0 \%$ & $14.4 \%$ & $14.5 \%$ & $20.0 \%$ & $27.0 \%$ & $10.1 \%$ & $10.9 \%$ & $25.1 \%$ & $19.1 \%$ & $12.6 \%$ & $14.6 \%$ \\
\hline Cropland & $44.2 \%$ & $59.2 \%$ & $56.0 \%$ & $37.0 \%$ & $31.4 \%$ & $68.6 \%$ & $68.1 \%$ & $27.8 \%$ & $34.0 \%$ & $64.6 \%$ & $52.9 \%$ \\
\hline Urban/residential & $2.4 \%$ & $1.6 \%$ & $2.6 \%$ & $2.8 \%$ & $1.9 \%$ & $2.4 \%$ & $1.5 \%$ & $2.4 \%$ & $2.6 \%$ & $1.4 \%$ & $3.0 \%$ \\
\hline \multicolumn{12}{|l|}{ Soils* } \\
\hline Lindley & $22.5 \%$ & $6.7 \%$ & $8.3 \%$ & $24.6 \%$ & $3.6 \%$ & $0.0 \%$ & $3.6 \%$ & $56.2 \%$ & $24.4 \%$ & $14.2 \%$ & $21.0 \%$ \\
\hline Armstrong & $12.3 \%$ & $0.0 \%$ & $0.0 \%$ & $0.0 \%$ & $0.0 \%$ & $0.0 \%$ & $0.0 \%$ & $12.7 \%$ & $39.0 \%$ & $0.1 \%$ & $0.0 \%$ \\
\hline Weller & $1.1 \%$ & $0.0 \%$ & $0.0 \%$ & $0.0 \%$ & $23.4 \%$ & $0.0 \%$ & $0.0 \%$ & $0.0 \%$ & $0.0 \%$ & $0.0 \%$ & $0.0 \%$ \\
\hline Putnam & $12.0 \%$ & $0.0 \%$ & $0.0 \%$ & $4.5 \%$ & $18.4 \%$ & $50.5 \%$ & $49.0 \%$ & $0.0 \%$ & $0.8 \%$ & $0.0 \%$ & $25.4 \%$ \\
\hline Mexico & $43.2 \%$ & $91.8 \%$ & $91.7 \%$ & $61.9 \%$ & $32.9 \%$ & $38.9 \%$ & $43.8 \%$ & $22.3 \%$ & $21.5 \%$ & $85.1 \%$ & $49.1 \%$ \\
\hline Bardley & $1.0 \%$ & $0.0 \%$ & $0.0 \%$ & $0.0 \%$ & $7.6 \%$ & $9.3 \%$ & $0.0 \%$ & $0.0 \%$ & $0.0 \%$ & $0.0 \%$ & $0.0 \%$ \\
\hline Fatima & $6.4 \%$ & $1.5 \%$ & $0.0 \%$ & $8.8 \%$ & $0.5 \%$ & $0.0 \%$ & $3.6 \%$ & $8.7 \%$ & $11.5 \%$ & $0.0 \%$ & $4.5 \%$ \\
\hline Edina & $0.2 \%$ & $0.0 \%$ & $0.0 \%$ & $0.0 \%$ & $0.0 \%$ & $0.0 \%$ & $0.0 \%$ & $0.0 \%$ & $0.9 \%$ & $0.0 \%$ & $0.0 \%$ \\
\hline Other & $1.3 \%$ & $0.0 \%$ & $0.0 \%$ & $0.2 \%$ & $13.6 \%$ & $1.3 \%$ & $0.0 \%$ & $0.1 \%$ & $1.9 \%$ & $0.6 \%$ & $0.0 \%$ \\
\hline
\end{tabular}

* Primary soil taxonomic groups: Lindley and Bardley, Typic Hapludalfs; Armstrong, Aquertic Hapludalfs; Weller, Aquertic Chromic Hapludalfs; Putnam, Vertic Albaqualfs; Mexico, Vertic Epiaqualfs; Fatima, Fluvaquentic Hapludolls; Edina, Vertic Argialbolls.

809 to $909 \mathrm{~mm}$ (32 to 36 in). These recent precipitation data are very comparable to the historic data for the basin, which was in the range of 889 to $940 \mathrm{~mm}$ (35 to 37 in) (US Army Corps of Engineers 1975).

Watershed History. Existing soil and water conservation concerns in the Salt River Basin are best understood within the context of historical settlement patterns of the last two centuries. Prior to European settlement, Native American habitation of the Salt River Basin was focused on hunting, gathering, and some agriculture cultivation (Henning 1975). The Salt River Basin underwent dramatic change with the 1803 Louisiana Purchase. Compared to other parts of the Midwest, movement of settlers into the basin was inhibited due to poor transportation routes. Game trails were gradually worn into wagon roads during the 1820s, and settlement became more widespread throughout the basin. Land purchase and settlement expanded rapidly from 1827 to 1836 , with $~ 80 \%$ of the public land within the basin purchased during this decade (O'Brien 1984). Throughout most of the 1800 s, homesteads were upland to avoid flooding and in or adjacent to timber, an essential resource for building and heating (O'Brien 1984). The nearly flat prairie grassland was mainly used for free-roam grazing.
Commerce was initially limited with settlers living a simple lifestyle growing corn, wheat, rye (Secale cereale), pumpkin and squash (Cucurbita spp.), garden vegetables, and typically only a few livestock. From the mid to late 1800 s, land clearing occurred for larger faming operations. Development of roadways led to commercialization and economic diversification that included grist mills, lumber mills, brick yards, and cash crops such as tobacco (Nicotiana spp.), hemp (Cannabis sativa), and cotton (Gossypium sp.) (O'Brien 1984). Cattle were primarily raised and fattened on grassland for the St. Louis market.

Early in the 1900s, the face of the Midwest rural landscape, including the Salt River Basin, underwent a major transformation. Many smaller communities began shrinking, farms increased in size, and people began migrating to the larger metropolitan cities (Bratton and Smith 1928). At the same time, improvements in agricultural mechanization helped affluent farmers expand their enterprises. As farms grew, most were integrated with grain and animal (cattle, hogs, and sheep) production. Extensive flat grasslands were plowed and put into grain production for the first time, typically growing corn, oats (Avena sativa), wheat, and a new crop, soybean. During World War I, corn grain prices soared, and so did corn acreage. This major shift in land use and intensity in the early 1900s had an immediate impact on the rivers and streams. Prior to the war, much of the Salt River was noted to have clear, clean water during most of the year (Howard 1980). Fish and mussels were plentiful. By the 1930s, the streams were sedimentfilled and fish were disappearing. Not by coincidence, the first soil erosion plot research in the United States was initiated in 1917 on similar soils on the campus of University of Missouri ( 50 km [ 30 mi] southeast of the Salt River Basin; Troeh et al. 1980). Grain crop yields for many fields actually declined when compared to the previous century (Bennett 1939).

The trend of fewer and larger farms continued through much of the 20th century as motorized equipment increased in size and efficiency. In 1950, agriculture employed $33 \%$ of the labor force in the Salt River area (US Army Corps of Engineers 1975). Over the next two decades, the number of cropped acres increased almost $10 \%$ while the labor force employed by agriculture decreased to less than 15\%. During the 1970s and 1980s, many small to medium-sized farms abandoned animal operations because of poor profitability and focused on grain produc- 
tion. Also during this period, a much higher percentage of farmland became lease-farmed instead of owner-farmed. A sequence of aerial photos (figure 2) obtained from the USDA Farm Service Agency archives illustrate for a typical field in the Salt River Basin some of the important changes during the 20th century: (1) larger fields by merging of smaller fields, (2) loss of farmsteads, (3) loss of integrated grain and animal production systems, and (4) return of indigenous trees along waterways and field boundaries. Current land use for the Salt River Basin and its subbasins is provided in table 1.

\section{Primary Soil and Water Conservation Concerns}

Surface Water. Streams in the basin have a well-documented history of herbicide and sediment contamination problems (National Academy of Sciences 1986; Donald et al. 1998; Ghidey and Alberts 1998; Blanchard and Lerch 2000; USDA NRCS 2000b; Lerch and Blanchard 2003). As previously mentioned, soils within MLRA 113 are characterized by the presence of a naturally formed subsurface claypan that creates a barrier to percolation and promotes surface runoff. This results in a high degree of vulnerability to surface transport of sediment and herbicides (National Academy of Sciences 1986; USDA NRCS 2000b; Lerch and Blanchard 2003).

In the early 1980s, average soil erosion rates for cropland within MLRA 113 were estimated to be $17.9 \mathrm{Mg} \mathrm{ha}^{-1}$ (8.0 tn $\mathrm{ac}^{-1}$ ) (National Academy of Sciences 1986), exceeding the "tolerance" factor $(\mathrm{T})$ of 7.6 $\mathrm{Mg} \mathrm{ha} \mathrm{h}^{-1}\left(3.4 \mathrm{tn} \mathrm{ac}^{-1}\right)$ by about 2.4 times. More recently, the USDA NRCS used their National Resources Inventory (USDA NRCS 2000b) data and the Universal Soil Loss Equation to estimate that in the state of Missouri $62 \%$ of cropland within MLRA 113 still exceeded $\mathrm{T}$ compared to $<50 \%$ of cropland in the other intensively row cropped MLRAs of the state (figure 3). Partitioning of the MLRA 113 cropland exceeding T into discrete multiples of $\mathrm{T}$ showed that $53 \%$ was in the $1 \mathrm{~T}$ to $2 \mathrm{~T}$ category, $24 \%$ was in $2 \mathrm{~T}$ to $3 \mathrm{~T}, 9 \%$ was in $3 \mathrm{~T}$ to $4 \mathrm{~T}, 5 \%$ was in $4 \mathrm{~T}-5 \mathrm{~T}$, and $9 \%$ was $>5 \mathrm{~T}$. Despite a lower erosion potential than several of the other MLRAs (National Academy of Sciences 1986), cropland erosion in MLRA 113 remains a major water and soil quality problem for this area as a whole and for the Salt

\section{Figure 2}

Aerial photos of a Salt River Basin quarter section ( $\sim 65$ ha) showing predominant changes over the 2oth century, including (1) smaller fields combined to make larger fields, (2) loss of farmsteads, (3) loss of integrated grain and animal production systems, and (4) return of indigenous trees along waterways and field boundaries.
1939

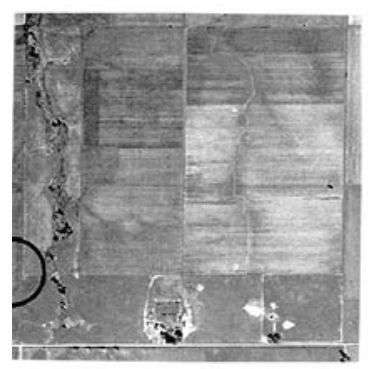

1956

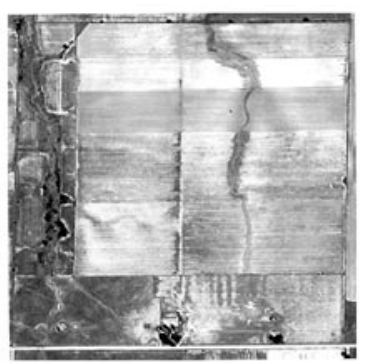

1982

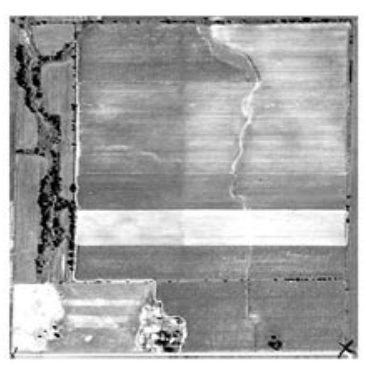

1968

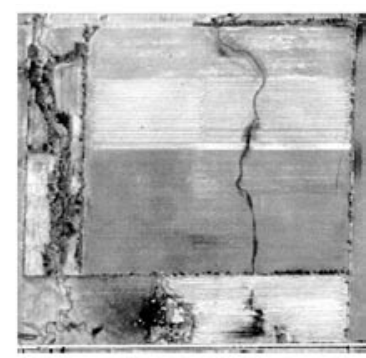

1990

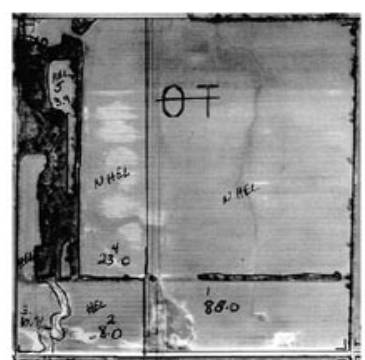

River Basin in particular. On claypan soils, a number of practices including reduced tillage, no-till, crop rotations that include wheat or grasses, and cover crops have been shown to effectively reduce soil erosion compared to conventional cropping systems (Jamison et al. 1968; Ghidey and Alberts 1998), and therefore, these conservation practices need

\section{Figure 3}

Estimated percentage of cropland with erosion exceeding $\mathrm{T}$ factor for the intensively row-cropped major land resource areas of Missouri.

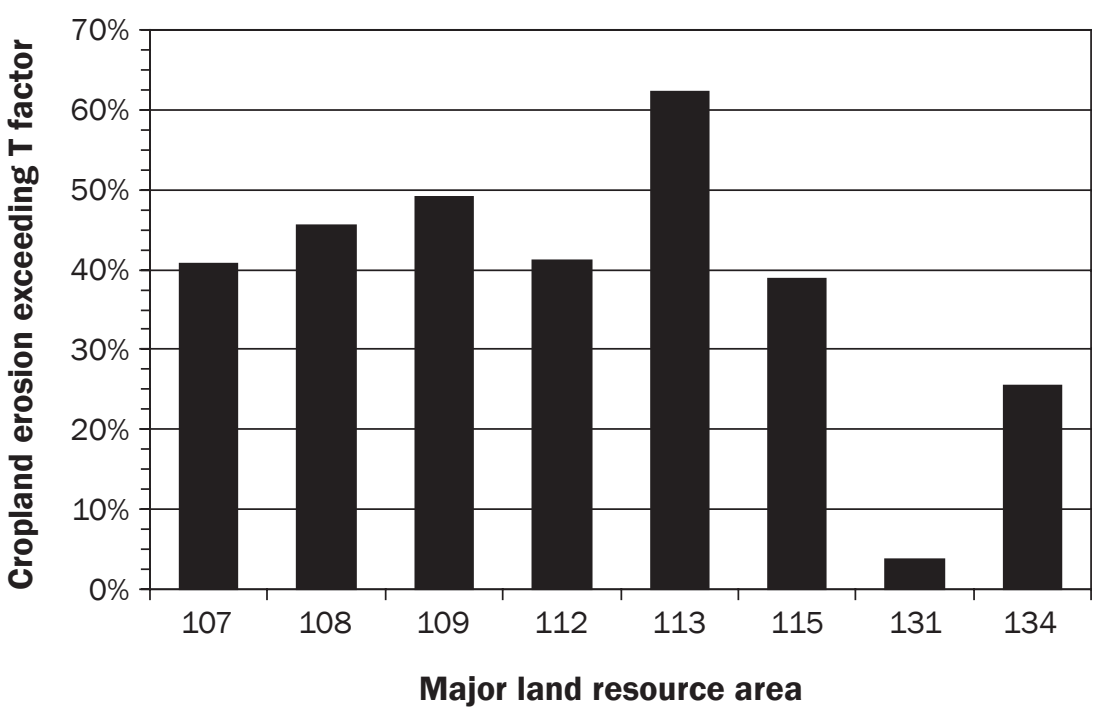

Note: T factor for major land resource area 113 is $7.6 \mathrm{Mg} \mathrm{ha}^{-1}$ (from USDA NRCS 2000b). 


\section{Figure 4}

Watershed vulnerability to herbicide transport expressed as the sum of six herbicide (atrazine, cyanazine, acetochlor, alachlor, metolachlor, metribuzin) and four metabolite (deethylatrazine, deisopropylatrazine, hydroxyatrazine, cyanazine amide) losses on a treated area basis (from Lerch and Blanchard 2003).

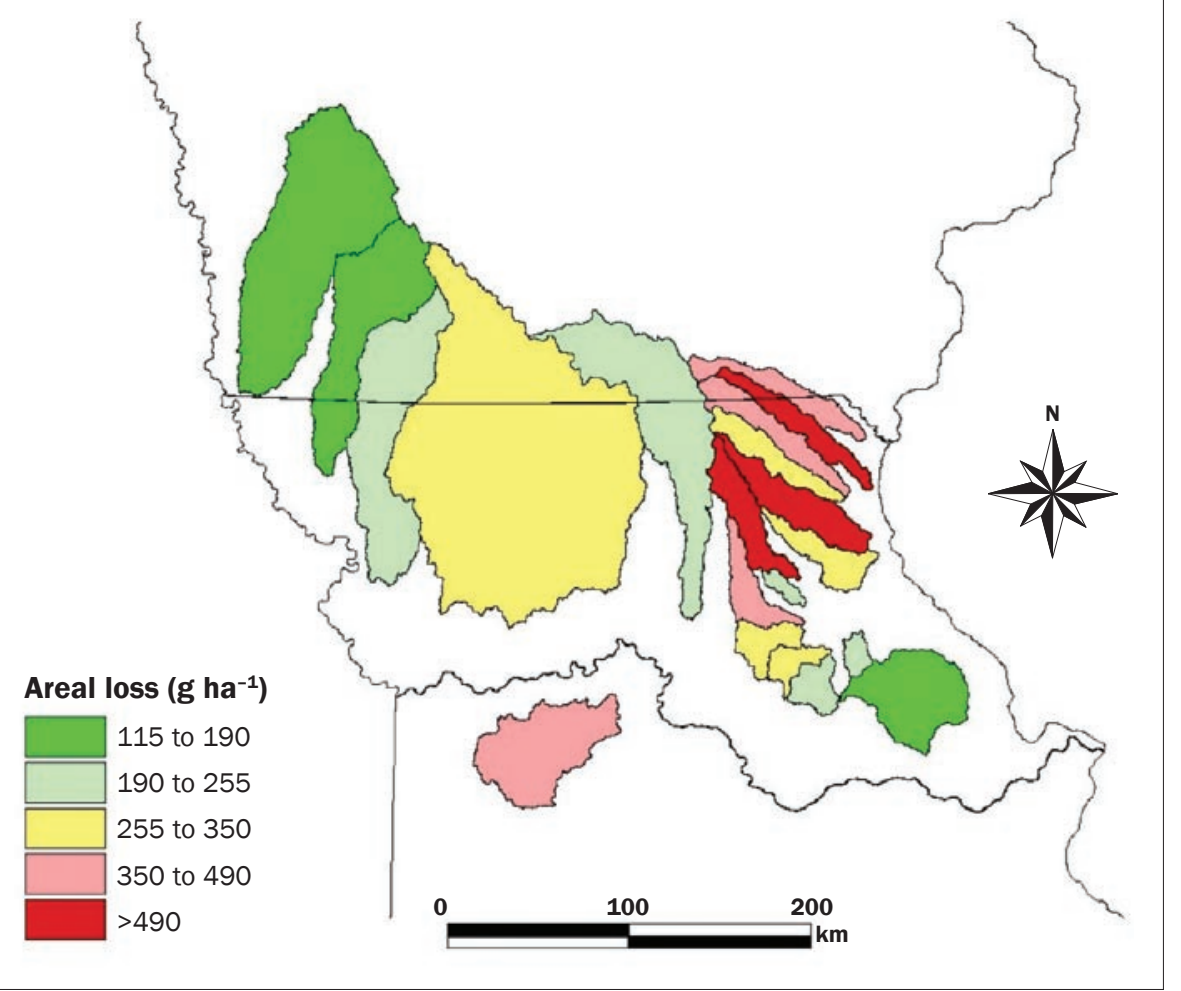

to be more widely implemented to decrease erosion rates.

Streams within the Salt River Basin have frequent detections of commonly used corn and soybean herbicides, particularly in the spring following herbicide application to fields (Donald et al. 1998; Blanchard and Lerch 2000; Lerch and Blanchard 2003). In Goodwater Creek (figure 1), peak concentrations of atrazine and metolachlor were observed from May to July, and maximum reported concentrations of atrazine and metolachlor were $62.4 \mu \mathrm{g} \mathrm{L}^{-1}$ (62.4 parts per billion [ppb]) and $39.5 \mu \mathrm{g} \mathrm{L}^{-1}$ (39.5 ppb), respectively (Donald et al. 1998). Similar seasonal trends for herbicide contamination in streams of the northern Missouri/southern Iowa region were also reported by Blanchard and Lerch (2000). The streams of MLRA 113 had the overall highest atrazine and cyanazine concentrations observed for the northern Missouri/southern Iowa region (Blanchard and Lerch 2000). Furthermore, MLRA 113 streams and those streams in watersheds with similarly high proportions of runoff-prone soils (e.g., extreme northeastern Missouri) had the highest herbicide loss, as a percent of applied, and were among the highest in overall vulnerability to surface transport

\section{Table 2}

Suggested indicators and functional relevance for assessing and monitoring soil quality on landscapes in the Salt River Basin.

\begin{tabular}{ll}
\hline Soil quality indicator & Functional relevance \\
\hline Water infiltration & Runoff, leaching, compaction and/or soil erosion potential
\end{tabular}

Water-stable aggregation

Bulk electrical conductivity

Soil organic matter, soil organic carbon

Active soil carbon (particulate organic matter)

Microbial biomass and/or respiration

Soil enzyme activity

Microbial diversity

Pesticide degradation
Water transport, microbial habitat (nutrient transformations, pesticide degradation), plant root growth

Topsoil depth, soil erosion, soil restoration

Key factor influencing biological activity, soil structure, soil fertility, plant nutrition

Specifically related to microbial respiration and biomass, soil aggregation

Biological activity, impact of management on soil organic matter or soil organic carbon

Soil microbial activity, nutrient transformation, management impacts on decomposition, xenobiotic degradation potential

Balance of principal nutrient cycles, multifunctional performance of soil

Environmental buffer, filtering effects, environmental contamination potential 
Table 3(a)

Infrastructure and historical data available for the Missouri Conservation Effects Assessment Project.

\begin{tabular}{|c|c|c|c|}
\hline \multirow[b]{2}{*}{ Originating project } & \multicolumn{2}{|c|}{ Goodwater Creek Experimental Watershed } & \multirow{2}{*}{$\begin{array}{l}\text { Mark Twain Lake/Salt River Basin } \\
\text { Conservation Effects Assessment Project, } \\
\text { Mark Twain Lake/Salt River Basin }\end{array}$} \\
\hline & $\begin{array}{l}\text { North Central } \\
\text { Research Watershed, } \\
\text { Goodwater Creek } \\
\text { Experimental Watershed }\end{array}$ & $\begin{array}{l}\text { Management Systems } \\
\text { Evaluation Area and } \\
\text { Agricultural Systems for } \\
\text { Environmental Quality }\end{array}$ & \\
\hline Period & 1971 to present & 1990 to present & 2005 to present (some records extracted 1990 to present) \\
\hline \multirow[t]{4}{*}{ Measurements } & Stream stage and flow & Stream stage and flow (all scales) & $\begin{array}{l}\text { Stage and flow (USDA Agricultural Research Service, } \\
\text { US Geological Survey) }\end{array}$ \\
\hline & Rainfall & Rainfall & $\begin{array}{l}\text { Rainfall (National Weather Service, } \\
\text { USDA Farm Service Agency) }\end{array}$ \\
\hline & Pan evaporation & $\begin{array}{l}\text { Water quality: nitrate, ammonium, } \\
\text { ortho-phosphate, sediment, } \\
\text { atrazine, deethylatrazine, } \\
\text { deisopropylatrazine, cyanazine, } \\
\text { alachlor, acetochlor, metolachlor, } \\
\text { metribuzin }\end{array}$ & $\begin{array}{l}\text { Automated weather stations: air temperature, rainfall, } \\
\text { humidity, solar radiation, wind direction, wind speed, } \\
\text { soil temperature (USDA Agricultural Research Service, } \\
\text { University of Missouri) }\end{array}$ \\
\hline & Water table elevation & Water table elevation & $\begin{array}{l}\text { Water quality: nitrate, ammonium, ortho-phosphate, } \\
\text { sediment, atrazine, deethylatrazine, deisopropylatrazine, } \\
\text { simazine, alachlor, acetochlor, metolachlor, metribuzin }\end{array}$ \\
\hline
\end{tabular}

of six parent herbicides and four metabolites (Lerch and Blanchard 2003) (figure 4). Because of this vulnerability, atrazine contamination in Mark Twain Lake caused it to be placed on the impaired waters list (303d) by the Missouri Department of Natural Resources from 1998 to 2002.

A major challenge associated with claypan soils is the need to develop cropping systems that concurrently facilitate incorporation of herbicides to reduce their transport in surface runoff, but maintain sufficient crop residue cover to control soil erosion. These two goals often conflict since effective erosion control measures, such as no-till, preclude the incorporation of herbicides. Thus, herbicide application methods must be found that can incorporate soil-applied herbicides and maintain residue cover to levels at or near that of no-till systems.
Groundwater. Because of slow infiltration, water drainage into groundwater is minor compared to surface water discharge (Blevins et al. 1996; Kitchen et al. 1998). When groundwater recharge occurs, it is primarily through preferential pathways such as decayed root channels or soil cracks that develop during droughts (Blevins et al. 1996). Percolation through the claypan is especially low in spring and early summer (the period of most herbicide and fertilizer applications) because the clay within the argillic horizon has swollen with fall and winter precipitation (Kitchen et al. 1998). Thus, compared to other agricultural areas of the US Midwest, groundwater is less vulnerable to contamination (Power et al. 2001). Still, groundwater surveys found nitrate leaching has contaminated the glacial till aquifer (Lerch et al.2005). However, herbicide leaching to groundwater was minimal in this same setting (Blanchard and Donald 1997). Twenty-five percent of the wells in the Goodwater Creek watershed were found to be contaminated with nitrate at concentrations $>10 \mathrm{mg} \mathrm{L}^{-1}$ (Kitchen et al. 1997). The conclusion of this assessment was that elevated groundwater nitrate concentrations were the result of multiple years of over-application of $\mathrm{N}$ for crops, either from synthetic fertilizers, animal manure applications, or both. Because of the buffered nature of the aquifer, elevated nitrate concentrations can persist for decades (Kitchen et al. 1997).

Soil. The primary soil conservation concerns of cropland erosion and transport of herbicides, nutrients, and sediments in runoff (Lerch et al. 2005) are also related to degradation of soil quality and provide a benchmark for evaluating management practices for improving soil quality. Soil quality 
Table 3(b)

Infrastructure and historical data available for the Missouri Conservation Effects Assessment Project (continued).

Goodwater Creek Experimental Watershed Mark Twain Lake/Salt River Basin

Time series data

Rainfall Obtained by USDA Agricultural Research Service

USDA Farm Service Agency Observer network provided by USDA National Agricultural Statistics Service, Gene Danekas, Director (http://www.cocorahs.org/ Media/docs/CoCoRaHS_2005_Brochure_LR.pdf)

Rainfall and temperature $\max / \min$

Automated weather stations

Obtained by USDA Agricultural Research Service

Stream stage and flow

Obtained by USDA Agricultural Research Service
National Weather Service Observer network provided by Patrick Guinan (Extension assistant professor of climatology, Department of Soil, Environmental and Atmospheric Sciences, University of Missouri)

Agricultural Electronic Bulletin Board provided by Patrick Guinan (http://agebb.missouri.edu/weather/ history/index.asp)

US Geological Survey (http://waterdata.usgs.gov/mo/nwis)

\section{Common ancillary data in geographic information system layers}

\begin{tabular}{ll}
\hline $\begin{array}{l}\text { Digital } \\
\text { elevation } \\
\text { model }\end{array}$ & $\begin{array}{l}\text { Center for Agricultural, Resource and Environ } \\
(10-\mathrm{m} \text { buffered ESRI grid of the 10-digit water } \\
\text { (http://www.cares.missouri.edu) }\end{array}$ \\
SSURG0, & SSURGO (http://www.ncgc.nrcs.usda.gov/ \\
STATSG0, & $\begin{array}{l}\text { products/datasets/ssurgo) } \\
\text { STATSGO (http://www.ncgc.nrcs.usda.gov/ } \\
\text { products/datasets/statsgo) }\end{array}$
\end{tabular}

Land use

Missouri Spatial Data Information Service (www.msdis.missouri.edu)

Boundaries
Center for Agricultural, Resource and Environmental Systems (http://www.cares.missouri.edu)
Missouri Spatial Data Information Service (30-m grid)

(http://www.msdis.missouri.edu)

STATSGO (http://www.ncgc.nrcs.usda.gov/ products/datasets/statsgo)

Missouri Spatial Data Information Service (http://www.msdis.missouri.edu)

Better Assessment Science Integrating Point and Non-Point Sources

(www.epa.gov/waterscience/basins) is perceived as the ability of soil to perform various functions to support optimal biological activity and diversity for plant and animal productivity, to regulate water flow and storage, and to provide an environmental buffer to mitigate effects of hazardous compounds (Karlen et al. 1997; Nortcliff 2002; Locke and Zablotowicz 2004). Assessment of soil quality within the Salt River Basin, specifically in the Goodwater Creek Experimental Watershed (GCEW), has focused on selected indicators (table 2) that encompass each group of soil properties and their interactions. Soil quality research has focused on surveys of selected soils, landscapes, and cropping systems to determine measurable soil attributes that best describe the condition of soils within GCEW. The selected soil attributes (table 2) were used to monitor soil quality improvement of established management practices. Soil erosion was a suitable guide for selecting the most appropriate indicators to describe prevailing soil conditions and monitor soil quality improvement. Topsoil depth, measured by apparent electrical conductivity, was also a useful indicator to demonstrate severe erosion on fields historically subjected to intensive tillage and extensive soil quality degradation (Jung et al 2005; Lerch et al. 2005).

Soil quality assessment to monitor agronomic and conservation management practices for improving soils in GCEW demonstrated the benefits of maintaining vegetation and crop residues on claypan soils (Kremer and Li 2003; Lerch et al. 2005). Crop rotation with no-till and permanent vegetation under the Conservation Reserve Program (CRP) provided higher microbial activity, soil organic $\mathrm{C}$, and water-stable aggregates than short rotation (corn-soybean) with minimum tillage and no cover cropping. Similarly, Staben et al. (1997) reported the most significant benefits of management systems with periods of permanent vegetation are the increases in soil organic matter and soil tilth, because numerous other soil properties are influenced. Increases in soil quality of cropping systems that include continuous vegetation improve soil function by providing a favorable ecosystem for biological processes that promotes crop growth and enhances environmental aspects, including water quality.

The ability of soil to function in pesticide dissipation has also been suggested as a primary soil quality indicator (Locke and Zablotowicz 2004). High concentrations of pesticides in runoff from crop production fields may reflect degraded soil quality 
because the environmental buffer capacity of soil to filter and process contaminants in water has been compromised. A study at one field site in GCEW revealed that atrazine degradation by microbial consortia in Mexico silt loam was higher than in Moniteau silt loam, partly due to long-term cultivation of corn on the Mexico silt loam in which corn rhizospheres provided a selective environment for microorganisms highly effective in degrading atrazine (Stanley 1999). Subsequent studies verified the impact of plants on atrazine and carbofuran dissipation at 15 days after application when both pesticides were reduced by $50 \%$ in the upper $10 \mathrm{~cm} \mathrm{(4} \mathrm{in)} \mathrm{of} \mathrm{Putnam}$ silt loam under corn compared with fallow soil (Buyanovsky et al. 1995). More importantly, no atrazine was detected below the 20-cm (8-in) depth under corn compared with $15 \mathrm{ng}$ atrazine $\mathrm{kg}^{-1}$ soil under fallow. Populations of presumptive carbofuran- and atrazine-degrading microorganisms were 3 to 5 times greater in corn rhizospheres, likely responsible for reduced pesticide concentrations in the $0-$ to $20-\mathrm{cm}$ depth. These studies provided a baseline for establishing the extent of pesticide dissipation and prevalence of presumptive pesticide-degrading microorganisms present in soils within the Salt River Basin. Our results parallel studies conducted in the Mississippi Delta, which demonstrated that atrazine in soil may be reduced about $50 \%$ by the microbial community when the herbicide was applied more than once every 24 months (Krutz et al. 2007).

Development of a suitable set of soil quality indicators (table 2) representing multiple functions of soil at a watershed scale continues to evolve as environmental impacts of management are documented. These indicators will be used to assess impacts of agronomic and conservation practices (i.e., grass and riparian buffers) on soil and water quality on landscapes within the Salt River basin. Future development of rapid and sensitive soil quality monitoring of soil management will contribute to the database for conservation assessment.

\section{Experimental Infrastructure and Legacy Data}

In the Mark Twain Lake/Salt River CEAP project, experimental infrastructure has been installed by USDA Agricultural Research Service as part of three separate projects in addition to several other ongoing monitoring efforts that are part of larger-scale networks. The GCEW was created in 1971, with stream weirs at and nested within a $72 \mathrm{~km}^{2}\left(28 \mathrm{mi}^{2}\right)$ drainage area. The instrumentation emphasized surface water hydrology (table 3). In 1990, the Missouri Management Systems Evaluation Area (Ward et al. 1994) project added an emphasis on surface and ground water quality and added field (20 to 36 ha [49 to $89 \mathrm{ac}$ ) and plot (0.35 ha [0.86 ac]) scales. The follow-up to Missouri Management Systems Evaluation Area, the Agricultural Systems for Environmental Quality project, continued a similar emphasis and infrastructure. The aggregated infrastructure for these two periods is described in Sadler et al. (2006a).

Beginning in 2005, the Mark Twain Lake/ Salt River Basin CEAP project emphasized a much larger scale assessment of benefits from conservation practices. A water quality monitoring network was established at 13 sites within the Salt River Basin (figure 1). Two basic approaches are being used (1) a multi-scale water quality assessment in Long Branch Creek watershed and (2) a basinscale mass balance assessment of contaminant loads discharged into and out of Mark Twain Lake. The multi-scale assessment of Long Branch includes four sites ranging in area from $72 \mathrm{~km}^{2}$ (27.8 $\mathrm{mi}^{2}$ ) (Goodwater Creek) to $469 \mathrm{~km}^{2}$ (181 $\mathrm{mi}^{2}$ ) (Long Branch Creek), with two intermediate sized watersheds. The basin-scale mass balance assessment includes nine of the ten watersheds (Ely Creek was excluded) within the basin and one site at the outlet of Mark Twain Lake. This monitoring scheme encompasses 71\% of the area above Mark Twain Lake, with individual watersheds having $63 \%$ to $94 \%$ of their watershed areas monitored. Sampling protocols at all sites include collection of baseflow and runoff samples. Grab samples are collected a minimum of twice monthly under baseflow conditions and after each runoff event. Runoff samples are collected with automated samplers. A single composite sample is collected for each runoff event with subsamples collected at equal flow intervals for the first $2.54 \mathrm{~cm}$ (1 in) of runoff. Autosamplers are deployed from April through November, and grab samples are taken year-round. Routine analyses include total and dissolved $\mathrm{N}$ and $\mathrm{P}$, common soil applied herbicides and two atrazine metabolites (acetochlor, alachlor, atrazine, deethylatrazine, deisopropylatrazine, metolachlor, metribuzin, and simazine) and total suspended sediment. This sampling scheme will allow for assessment of contaminant concentrations under baseflow and runoff conditions and will facilitate computation of contaminant loads. In addition, the monitoring program will be used to identify watersheds contributing the highest proportion of the contaminant loads to Mark Twain Lake, and for calibration and validation of the Soil and Water Assessment Tool (SWAT) model simulations (see below).

Operating over an area the size of the Salt River Basin necessitated leveraging infrastructure and data from many sources, as seen in table 3. A key resource was the USGS gauging station network, which monitors stream stage and flow for eight of the 13 sites (North Fork at Shelbina, Crooked Creek, Lick Creek, Middle Fork, Elk Fork, Lower Long Branch, South Fork, Clarence Cannon Dam outlet), leaving five additional sites for the current project (figure 1). One of these is GCEW, which was in place. Another, Young's Creek, was a former USGS station, decommissioned in the 1970s, for which a rating curve existed that has been confirmed applicable over the range observed recently. That left only three sites that needed stage measurements installed and rating curves developed (Black Creek, Upper Long Branch, and Otter Creek).

The CEAP project also needs weather data, which exists in this region from three sources. The most detailed (hourly) data are collected by the University of Missouri automated weather station network at three sites in or near the Mark Twain Lake basin to the east (Auxvasse, Monroe City, Novelty), and one somewhat farther away to the west (Linneus; Agricultural Electronic Bulletin Board 2007). To this list is added the automated weather station within GCEW. These measure solar radiation, temperature, rainfall, wind speed, wind direction, and soil temperature. At the daily time basis, temperature extremes and rainfall are reported by the National Weather Service volunteer observer network, and rainfall is reported by the county USDA Farm Service Agency offices. In addition to these time series weather data, geographic information system layers provide spatial information needed for interpretation and computer modeling. These include soil data from USDA NRCS, digital elevation data from ESRI (Redlands, California), the US Environmental Protection Agency Better Assessment Science Integrating Point 
and Nonpoint Sources (BASINS) database, land use/land cover data from the Missouri Spatial Data Information Service, and stream networks and hydrologic area boundaries from the Center for Agricultural, Resource and Environmental Systems, University of Missouri (table 3).

\section{Evaluation of Best Management Practices}

Reducing Herbicide Transport with Vegetative Buffers. Multiple species vegetative buffer strips (VBS) have been recommended as an effective approach to mitigate herbicide transport in surface runoff derived from agronomic operations (Lin et al. 2003; Krutz et al. 2003; Krutz et al. 2004; USDA NRCS 2000a). However, the effect of buffer designs and species composition on reducing herbicide transport has not been well documented. A rainfall simulation study was conducted on an eroded Mexico silt loam soil to test the ability of different VBS treatments to mitigate herbicide transport in surface runoff. The study included four VBS treatments: (1) continuous cultivated fallow (control); (2) tall fescue (Festuca arundinacea Schreb.); (3) tall fescue with a 1-m (3.28$\mathrm{ft}$ ) wide switchgrass (Panicum virgatum L.) hedge at the upslope end of the VBS; and (4) native warm season grasses-mainly eastern gamagrass (Tripsacum dactyloides) and switchgrass. The effect of the VBS treatments on transport of three commonly used soilapplied herbicides - atrazine, glyphosate, and metolachlor-was studied. Full details of the experimental design and procedures can be found in work by Lin et al. (2007).

The results showed that allVBS treatments significantly reduced the transport of both dissolved and sediment-bound herbicides in surface runoff compared to the control. A much higher proportion (40\% to $60 \%$ ) of glyphosate was transported with suspended sediment in surface runoff as compared to that of atrazine and metolachlor $(<3 \%$ was sediment-bound). Four meters of native VBS removed about $75 \%$ to $80 \%$ of all three herbicides in surface runoff. In addition, $4 \mathrm{~m}(13.1 \mathrm{ft})$ of native species VBS resulted in much greater reductions in herbicide transport than $8 \mathrm{~m}(26.2 \mathrm{ft})$ of the two tall fescue VBS designs. The primary mechanism by which VBS reduced dissolved-phase herbicide transport was enhanced infiltration resulting from plant evapotranspiration and greater water holding capacity in the soil. This study also showed that the VBS were capable of increasing the infiltration of surface runoff for a high runoff potential claypan soil.

Crop Management System Best Management Practices. Development of cropping system BMPs for claypan soils began on the campus of University of Missouri with the establishment of Sanborn Field (1888) and later the Duley-Miller Erosion Plots (1917). These early nonreplicated plots documented that claypan soils are sensitive to rapid and severe soil degradation (e.g., topsoil erosion, loss of organic matter, loss of productivity) under some crop management practices (Woodruff 1987; Gantzer et al. 1990; Gantzer et al. 1991). With the Missouri Management Systems Evaluation Area project, investigations on crop management practices and development of BMPs have predominantly been conducted at the plot scale within GCEW $\left(39^{\circ} 13^{\prime} \mathrm{N}, 92^{\circ} 07^{\prime} \mathrm{W}\right)$. The area is divided into 30 0.35-ha plots, encompassing three landscape positions: summit, backslope, and footslope. The primary soils found at the site are poorly drained Mexico and Putnam silt loams. Established in 1991, these plots allow side-by-side comparison of tillage and rotation effects on crop production, runoff and water quality, and soil property changes. Unique about the research is the ability to look at interactions between management and landscape position. Additional description of the research area, crop management system operations, and sampling methodology has been documented previously (Kitchen et al. 1998; Ghidey et al. 2005a; Jung et al. 2007).

Our findings of how crop management practices affect claypan soil and water quality properties provide a basis for BMP implementation within the Salt River Basin. The findings include (1) growing season (i.e., April-October) runoff averaged over years was not different between tilled and no-till grain crop systems (figure 5), a finding that is in contrast to many other runoff studies of no-till cropping (Ghidey et al. 2005a); (2) herbicide concentration or mass loss was greatest for the first runoff event and decreased rapidly as the season progressed; (3) herbicide losses were approximately $120 \%$ higher from no-till systems than the tilled system (figure 5) primarily due to the lack of herbicide incorporation in the no-till systems (Ghidey et al. 2005a); (4) split herbicide application (pre- and postemergent) increased atrazine loss by creating two vulnerable periods for atrazine transport; (5) though no significant differences were found between cropping systems for seasonal losses of nitrate (figure 5) or orthophosphate, losses measured were among the highest reported when compared to other cropping system runoff research under natural rainfall conditions; (6) herbicide and nitrate leaching through the root zone was influenced more by intrinsic site-specific soil hydrology and climate factors than by cropping system input rates and application methods (Kitchen et al. 1998); (7) perennial grasses improved aggregate stability and soil organic carbon over all landscape positions (figure 6) (Jung 2005); (8) field-measured infiltration at the summit position was higher with perennial grass systems (CRP and hay) than with grain crop systems, but it was especially improved with the hay cropping system (figure 6) because of stimulated growth with $\mathrm{N}$ fertilization and biomass harvesting (Jung et al. 2007); (9) laboratory-assessed saturated conductivity on the backslope position for CRP and hay cropping systems was 16 and 10 times higher, respectively, than for the mulch-tilled grain system (figure 6) (Jiang et al. 2007); and (10) soil biological activity and microbial diversity were highest for perennial grass and integrated cropping systems (Kremer and $\mathrm{Li}$ 2003), indicating their effectiveness in improving soil quality by enhancing multiple soil functions. In some cases, the BMP for one desired outcome may be in opposition to a different desired outcome (e.g., no-till for erosion control can increase herbicide loss). In these cases, priorities will need to be established as described by Kitchen et al. (2005).

Precision Agriculture as a Best Management Practice. Producers' primary motivation for employing precision agriculture is to improve profitability. However, precision agriculture systems (PAS) can also provide environmental protection through reduced agrochemical use, increased nutrient-use efficiencies, and diminished off-field movement of soil and agrochemicals. From this premise, Berry et al. (2003) developed the idea of "precision conservation" and proposed that precision conservation ties efforts across scales (zones within fields to between fields to watershed and basin management) and is a key tool in achieving conservation goals. 
In the context of precision conservation, uses of site-specific information (e.g., yield maps, soil sampling) extend beyond the usual variable-rate management of inputs to managing parts of a field in completely different ways (e.g., cropping system, conservation measures). Such targeting of conservation practices is particularly important where erosion processes acting over time have accentuated the differences in soil across the landscape, as is the case with claypan soils (Lerch et al. 2005).

As a precursor to developing an integrated PAS for profitability and conservation, we intensively monitored crop, soil, and water quality information on Missouri claypan soils for over a decade (Lerch et al. 2005; Kitchen et al. 2005). These data showed considerable spatial variation in crop yield and soil properties. In general, soil texture and topsoil depth (as inferred by apparent soil electrical conductivity [Sudduth et al. 2003]), along with topography, had the most persistent relationships with yield because of their effect on soil water holding capacity and within field water redistribution (Drummond et al. 2003). The shape of the relationship was dependent on the climate during the particular growing season, specifically the amount of rainfall received in July and August (Jung et al. 2005).

We used soil, landscape, and profit maps to develop the PAS crop management plan addressing site-specific problems, and implemented it on a typical claypan-soil field in 2004 (Kitchen et al. 2005). Based on our analysis of previous data (Lerch et al. 2005), we gave equal priority to surface water quality and soil quality, and less priority to groundwater quality when determining what production and conservation measures were needed and where they should be placed. Shallow topsoil areas of the field were no longer planted to corn receiving soil-applied herbicides. Instead, these areas were planted to wheat and a cover crop, usually without herbicides, with a cover crop also used after corn on the remainder of the field. The PAS plan included variable fertilizer application based on grid soil sampling and fertility mapping for P, K, and lime. Nitrogen for corn and wheat were applied variably, relying on ground-based crop reflectance technologies that have been commercialized in recent years (Shanahan et al.2003). Additional PAS details are given by Kitchen et al. (2005).

\section{Figure 5}

Growing season runoff, atrazine loss, and nitrate-nitrogen loss (unpublished) as affected by three grain cropping systems farmed over a claypan soil landscape (from Ghidey et al. 2005a).

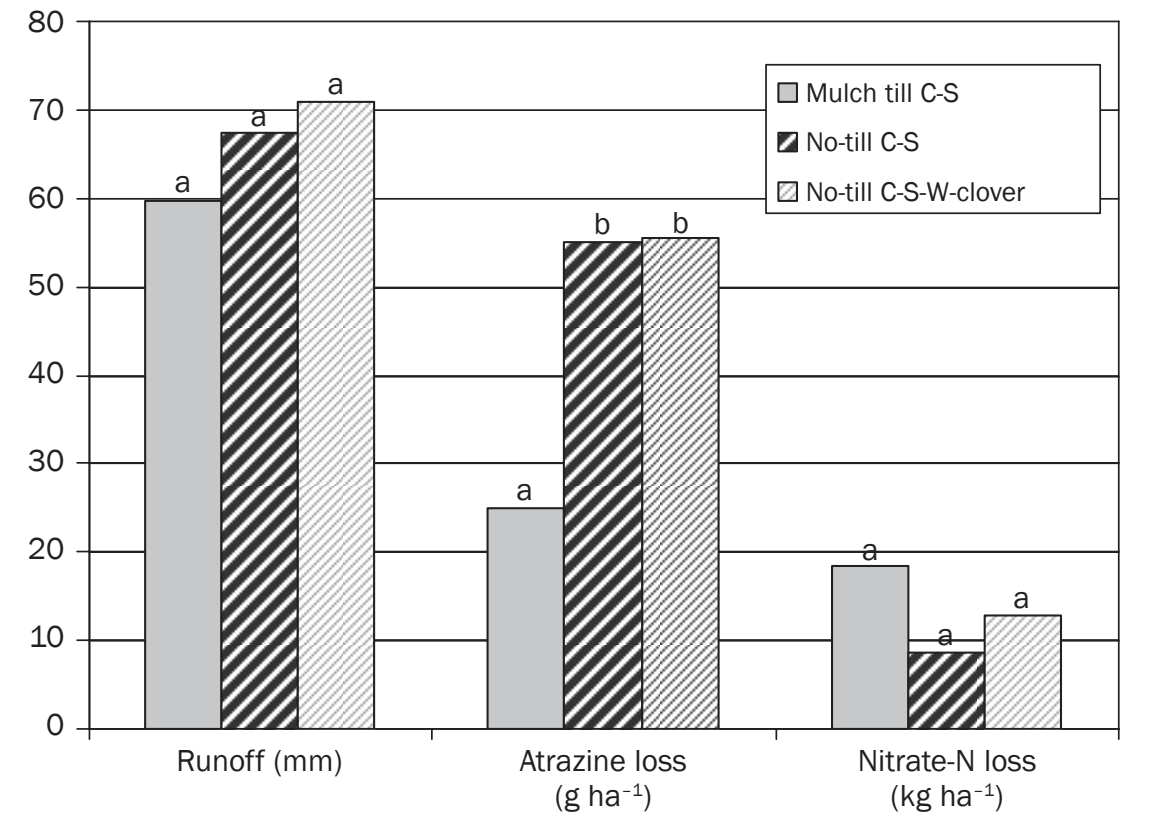

With the complex, integrative nature of this research effort, definitive results will not be obtained for a number of years. However, preliminary results indicate that PAS management is having positive environmental effects. There has been a reduction in profile soil nitrate concentrations, presumably through

a combination of variable $\mathrm{N}$ application and removal of excess $\mathrm{N}$ in the cover crop. In addition, the cover crop, along with notill and the wheat stubble and straw residue on part of the field, has begun to reduce soil erosion and runoff from sensitive sideslope areas. Prior to these changes, large rainfall

\section{Figure 6}

Soil organic carbon (Jung 2005), aggregate stability (Jung 2005), in-field quasi-steady infiltration rate (Jung et al. 2007), and laboratory saturated hydraulic conductivity (liang et al. 2007) as affected by three grain cropping systems, two Conservation Reserve Program systems, and a hay cropping system, averaged over a claypan soil landscape.

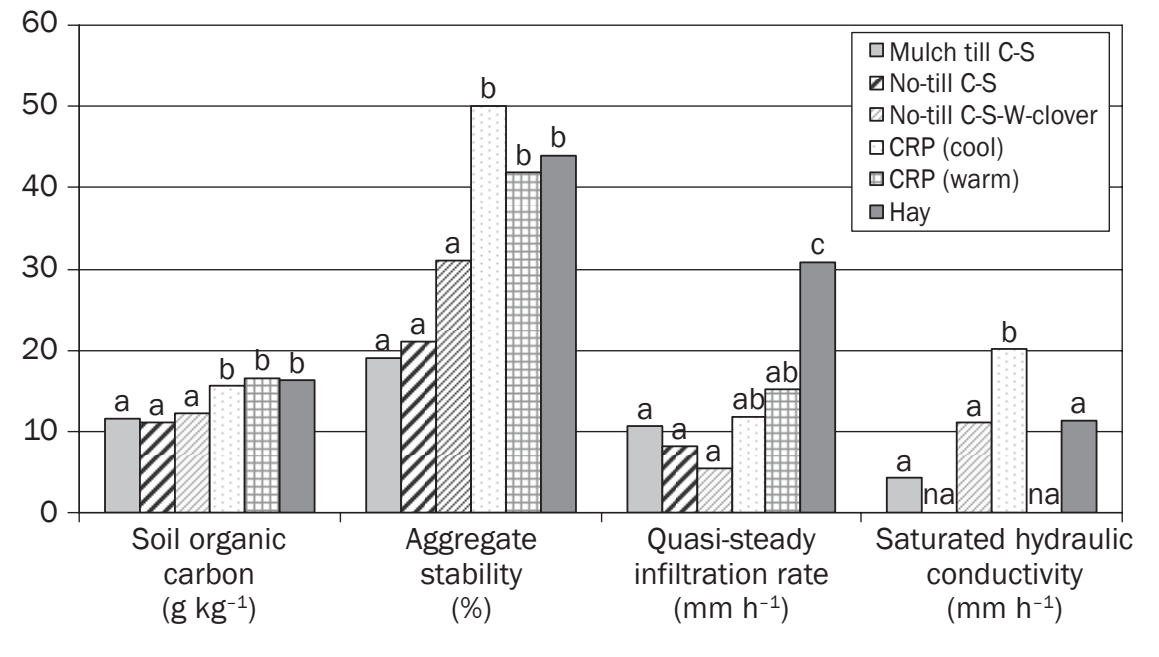




\section{Table 4}

Final values of goodness of fit indicators for the Goodwater Creek experimental watershed (Ghidey et al. 2007).

\begin{tabular}{|c|c|c|c|c|c|}
\hline \multirow{2}{*}{ Time step } & & \multicolumn{2}{|c|}{ Calibration 1993 to 1997} & \multicolumn{2}{|c|}{ Validation 1998 to 2003} \\
\hline & & $\overline{r^{2}}$ & $E_{\mathrm{NS}}$ & $\overline{r^{2}}$ & $E_{\mathrm{NS}}$ \\
\hline \multirow[t]{2}{*}{ Annual } & Flow & 0.92 & 0.87 & 0.93 & 0.92 \\
\hline & Sediment & 0.95 & 0.51 & 0.65 & 0.11 \\
\hline \multirow[t]{2}{*}{ Monthly } & Flow & 0.76 & 0.72 & 0.67 & 0.66 \\
\hline & Sediment & 0.58 & 0.47 & 0.49 & 0.33 \\
\hline \multirow[t]{2}{*}{ Daily } & Flow & 0.50 & 0.50 & 0.54 & 0.52 \\
\hline & Sediment & 0.46 & 0.45 & 0.16 & -0.20 \\
\hline
\end{tabular}

Note: NS = Nash-Sutcliffe coefficients.

events would often result in significant rilling and movement of soil from sideslopes to an alluvial area immediately above the field drainage outlet. After PAS establishment, similar rainfall events have caused much less rilling and no observed new deposition in the alluvial area.

A challenge in optimizing precision management is that no two fields are the same and therefore a priori specification of the best management system is difficult. Because of this, the PAS concept is adaptive, relying on the underlying spatial datasets to guide the application of conservation management to the most appropriate subfield areas. Rather than explicitly defining a precision agriculture BMP for application to the landscape, the "practice" in this case is the decisionmaking sequence that, in concert with the spatial characteristics of the field, allows the manager or advisor to uniquely define and place practices in a manner that is optimum for that particular field.

\section{Modeling Efforts and Needed Improvements to Models}

Soil and Water Assessment Tool Results to Date. Modeling efforts in the Mark Twain Lake/Salt River Basin started with the calibration and validation of the SWAT model for GCEW because of the extensive and detailed precipitation, flow, and water quality data available in the experimental watershed. Initial calibration and validation of SWAT results for GCEW were presented by Ghidey et al. (2005b). These results were preliminary in that they were based on flow data from 1993 to 2003 prior to a retrospective data quality analysis. A subsequent repeat of the model calibration and validation highlighted modeling and monitoring issues (Sadler et al. 2006b). Herbicides and sediment concentrations and loadings were found to be sensitive to factors related to the model and to errors associated with the stage-discharge rating curve developed for the $72 \mathrm{~km}^{2}\left(28 \mathrm{mi}^{2}\right)$ drainage area of GCEW. The modeling factors included (1) year-specific planting dates, and consequently herbicide application and tillage dates; (2) the spread of herbicide application dates over a period throughout the watershed, whose distribution is unknown; and (3) year-to-year crop distribution, which is a function of climate and economic factors. With respect to the discharge data, the confidence of the rating curve decreases as flow increases for various reasons, including fewer opportunities to make an actual measurement, increased difficulty making the measurement, and higher likelihood to have modifications of the higher bank profile over several decades. This uncertainty propagates to uncertainties in the model calibration and in the estimation of event, monthly, and annual pollutant loadings. The best model results were obtained using a 12-year rotation in order to specify yearly planting and atrazine application dates and to more accurately simulate the temporal spread in farming operations throughout the watershed. However, land use and crop distributions are fixed and cannot be changed in the model Final values of the $r^{2}$ and the Nash-Sutcliffe coefficients for flow and sediment concentration in GCEW are presented in table 4.

A recent comparison of modeling results with SSURGO and STATSGO data showed that although the final set of input parameter values were different, both sources of soil data led to similar goodness of fit during the calibration and validation periods (Ghidey et al. 2007). This result is encouraging in that calibration results in a small watershed of the region with STATSGO soil data can be scaled up to a larger watershed or to the river basin. Earlier studies show a variety of results concerning this issue. Di Luzio et al. (2004) showed an advantage in using SSUR GO rather than STATSGO data. Wang and Melesse (2006) obtained slightly better overall results with SSURGO, with the advantage being lessened when looking at specific ranges of flow conditions. Peschel et al. (2006) found differences in the results but did not evaluate the goodness of fit with either data set.

Modeled Effects of Best Management Practices. Sensitivity of SWAT to relevant management practices in the GCEW was also investigated (Sadler et al. 2005). Thirtyyear simulations were performed to contrast pre-herbicide tillage practices against current practices that utilize herbicide rather than tillage to control weeds. The analysis suggested, on average, sufficient sensitivity for continued study. Specific years that showed no differences may suggest avenues for exploring characteristics within the model or the measurements that dramatically affected sensitivity. In addition, unexplained differences related to phosphorus losses were detected during the 1970s in comparison to the later years (1980 to 1990s).

Statistical analyses of measured atrazine concentrations in samples collected at the outlet of GCEW showed significant concentration decreases for June and the combined months of April, May, and June from 1993 to 2003. Numerical, but not statistically significant, increases and decreases in atrazine concentrations were also observed in April and May, respectively (Bockhold et al. 2006). Several factors explain these trends. First, increased maximum and minimum daily temperatures in the spring led to earlier corn planting and atrazine applications. This allows more time for the chemical to degrade, leaving less to be detected in June. Second, several grass waterways have been implemented protecting as much as $9 \%$ of the watershed area by 2003 . We estimated that 652 ha $(1,611 \mathrm{ac})$ in corn-soybeans had grass waterways added to them from 1993 to 2003. Other factors such as changes in corn and sorghum acreage or in atrazine application rates were considered but not investigated because we did not have enough information to conclude whether there had been a change.

The SWAT model developed and calibrated for GCEW was utilized to estimate the impact of these climate and management factors. First, the simulated atrazine concentration data set was evaluated to determine if SWAT had reproduced the trends found in the measured atrazine data. This would mean that the results were affected by only 
weather and associated changes in planting and atrazine application dates. The linear regressions were tested for significance $(\alpha=0.05)$, and the direction of the regression was compared if found significant. The SWAT model was able to reproduce the significant decrease in June. Regressions that were not significant in the observed data (April and May) were also not shown to be significant in the modeled output. The model was not able to simulate the decline in concentration across the season of April, May, and June over the 11-year period. This may be because the model did not simulate a trend as strong as the observed data for June or because other factors contributed to the stronger decrease. The changes in amount of area protected by grass waterways were reflected through modifications of inputs in the SWAT model: slope lengths of these areas were divided in half and a 12-m wide filter strip was added. The effects of this scenario were simulated while holding weather constant to better understand its influence on atrazine levels. Model output obtained with and without grass waterways was compared using a paired t-test. Simulated results for the April, May, and June period and for the whole year (not shown) indicate that the historical implementation of this practice significantly decreased mean and median concentrations as well as the variance (table 5).

Improvements Needed. Predicted flow values appear to better match measured values for storm events than for low flow conditions, especially during drought years. While this may not represent a significant drawback for the analysis of pollutant transport with surface runoff, it does have implications for the analysis of nitrates and pesticides transported to the stream through the groundwater. In general, the simulation of groundwater processes needs to be improved. Snowmelt processes are a source of uncertainty in the model as well. A sensitivity analysis of the model parameters performed with the AVSWATX interface indicated that out of the 10 most sensitive parameters, three impact groundwater flows and three impact snowmelt. This has implications on the simulation of winter flows and may have implications on the amount of soil water present in the soil at the beginning of the planting season. Regarding sediment and pollutant concentrations, a better calibration of the model will be performed after the results of a recent farmer survey provide

Table 5

Atrazine concentration statistics from Soil and Water Assessment Tool simulations evaluating the effect of grass waterways in the Goodwater Creek experimental watershed (KoellingBockhold 2006).

\begin{tabular}{|c|c|c|c|}
\hline & $\begin{array}{l}\text { Mean } \\
\left(\mu \mathrm{g} \mathrm{L}^{-1}\right)\end{array}$ & $\begin{array}{l}\text { Median } \\
\left(\mu \mathrm{g} \mathrm{L}^{-1}\right)\end{array}$ & $\begin{array}{l}\text { Variance } \\
\left(\mu g \mathrm{~L}^{-1}\right)^{2}\end{array}$ \\
\hline Without grass waterways & 11.9 & 0.220 & $1.85 \times 10^{-3}$ \\
\hline With added grass waterways & 8.87 & 0.192 & $1.10 \times 10^{-3}$ \\
\hline
\end{tabular}

information about the specific practices used in the watershed, especially regarding tillage, herbicides, and crop distribution.

\section{Tools Needed for Improving Watershed Management}

Identifying Hydrologically Vulnerable Areas within Watersheds. The key to effectively addressing the contamination of water resources by agricultural chemicals is to properly target conservation practices to vulnerable landscape areas within watersheds. Vulnerability of any specific land tract is controlled by a combination of physical setting (e.g., soils and topography) and existing land management practices. Modeling landscape vulnerability to hydrologic transport of contaminants at a watershed scale requires integration of soil, chemical, and hydrologic properties of the watershed. This process should also include identification of nutrient, herbicide, and sediment sources and the transport pathways of the chemical contaminants (i.e., leaching, dissolved in surface runoff, or sediment-bound). One approach to identifying vulnerable areas within watersheds is the development of risk assessment index models based on assigning weights to a set of soil and chemical properties that control the fate of a particular contaminant. An example of this approach is the USDA NRCS index model, Windows Pesticide Screening Tool (USDA NRCS 2004), which provides a general landscape assessment of potential pesticide transport via leaching and runoff. However, this model uses hydrologic soil groups, a landscape-independent variable, to identify runoff prone areas in complex landscapes. This limitation suggests the need for an alternative approach that includes landscape-dependent variables, such as the index of surface runoff, and the use of the SSURGO (USDA NRCS 2005a) data sets for relevant soil parameters. These landscapedependent soil properties should then be combined with the properties of the contaminant-e.g., sorption intensity and degradation half-life for pesticides - to accurately identify the relative risks of water resource contamination. This approach is currently being pursued by a consortium of researchers representing the four US Environmental Protection Agency region 7 states (Kansas, Iowa, Missouri, and Nebraska).

Remote Sensing of Water Quality. As noted above, Missouri CEAP research includes a monitoring campaign to characterize the hydrologic balance and nutrient/ chemical loading to Mark Twain Lake. Because monitoring sites were located a significant distance upstream from the lake to avoid stagnant conditions at high lake stages, we sought to augment these data with remote sensing of water quality variations among the different arms of the lake. Others have reported success when using remote sensing to estimate suspended sediment, turbidity, chlorophyll, and phosphorus (Ritchie et al. 2003; Shafique et al. 2003).

In 2004, we collected hyperspectral water reflectance data with airborne and groundbased sensing systems for multiple arms of Mark Twain Lake. In 2005, we obtained ground-based field spectrometer data at two additional dates. Water samples were also collected and analyzed in the laboratory for chlorophyll, nutrients, and turbidity. Remotesensing estimates were of moderate accuracy $\left(r^{2}>0.6\right)$ for all parameters (Sudduth et al. 2006). As all measurements used in this study were obtained in summer, additional data collection is needed to verify the robustness of the results under other conditions, such as the high-flow events commonly caused by late-winter rainfall or snowmelt.

Crop Type Classification. Evaluating BMP effects on water quality at a watershed outlet requires information on the spatial distribution of various practices, including crop type, across the landscape. Crop type maps are produced annually from satellite data by USDA National Agriculture Statistics Service (Craig 2001). However, these maps cover only selected portions of the United States and were not available for the Salt River Basin. Also, the methodology used by USDA National Agriculture Statistics Service relies on their annual sampling data, which are not 
generally available. Therefore, we developed an alternative method incorporating multiple satellite remote sensing datasets to delineate land cover, including crop type, for the Mark Twain Lake/Salt River Basin (Jang et al. 2005). Overall crop type classification accuracy was approximately $84 \%$. Future work includes application of these procedures to develop crop type maps for a suite of growing seasons and use of the maps as input data for environmental analysis models.

Improved Soil Productivity Assessment Tool. Claypan soils of the Salt River Basin are often referred to as "marginal soils" because many are highly erodible and poor yielding. The environmental sustainability part of the 'marginal soil' concept is well defined for this region through soil and DEM maps, but soil productivity has not been well quantified. Yet information on productivity exists in the form of grain yield maps that farmers have obtained over the last decade using harvesters equipped with yield monitoring systems. This assessment starts with a synthesis of mapped soils and a large database of mapped grain yields in order to quantify the economic and environmental sustainability of marginal soils for the Salt River Basin. The outcome of this assessment will be information for landowners and managers as they compare different cropping systems on different soil types. The objective of this activity is to develop and use a decision support tool to assess the variability in areal extent and location of marginal soils given changing market forces and cropping system scenarios. This project will be useful for site-specific conservation planning, including nutrient management, and targeting of practices.

\section{Summary and Conclusions}

The Salt River Basin includes 10 major watersheds, ranging in area from 271 to $1,579 \mathrm{~km}^{2}$ (105 to $609 \mathrm{mi}^{2}$ ). These watersheds drain to Mark Twain Lake, the primary water supply in the region. The basin is characterized by flat to gently rolling topography with a predominance of claypan soils that are poorly drained and have slow permeability, resulting in high runoff potential. Initial AngloEuropean settlement in the basin occurred in the 19th century; small settlements near streams and subsistence agricultural practices prevailed during this time. In the 20th century, land use patterns evolved towards fewer and larger farms, a loss of farmsteads and integrated grain and animal operations, and a return of trees along riparian corridors. Today, the primary soil and water conservation concern is soil erosion, which has degraded both soil and water quality in the basin. Other significant water quality concerns are herbicide contamination of streams and nitrate contamination of groundwater.

The basin has had extensive experimental infrastructure installed over the last 35 years to study hydrology and contaminant transport. Federal agencies particularly emphasized the establishment of hydrologic and water quality monitoring stations throughout the basin. Because of this emphasis, extensive stream discharge and climate data sets from multiple sites are available. Moreover, the hydrologic infrastructure provides the stream discharge data needed for the monitoring network used to identify watersheds contributing the highest proportion of the contaminant loads to Mark Twain Lake and for calibration and validation of the SWAT model simulations. In the early 1990s, additional infrastructure was installed to study the effects of cropping and conservation BMPs at field and plot scales. Major results from multiple cropping system BMP studies showed that no-till cropping systems did not reduce surface runoff compared to tilled systems and led to increased transport of soil-applied herbicides because of a lack of incorporation. However, VBS were shown to be an effective conservation practice for reducing dissolved-phase and sediment-bound herbicide transport in surface runoff. Seasonal losses of nitrate and phosphate in surface runoff were among the highest reported in the literature, regardless of cropping system. Perennial grass systems, such as CRP and hay, maintain significantly greater soil quality and infiltration rates than grain crop systems. Results of SWAT model simulations for GCEW showed that the sediment and herbicide concentrations and loads were sensitive to year-specific planting progress, temporal spread in herbicide application, and annual changes in crop distribution. The model was also capable of simulating observed long-term trends in atrazine concentrations and the impact of grass waterways on atrazine concentrations. Additional research efforts are focused on the development of needed tools to improve watershed management. Such tools include the development and application of risk assessment models for targeting conserva- tion practices, the use of remote sensing for monitoring lake and reservoir water quality, development of algorithms for crop type classification to retrospectively estimate crop distribution patterns, and development of a soil productivity assessment tool to improve site-specific cropping system and conservation planning.

\section{Disclaimer}

Mention of trade names or commercial products in this publication is solely for the purpose of providing specific information and does not imply recommendation or endorsement by the USDA.

\section{References}

Agricultural Electronic Bulletin Board. 2007. Missouri Weather Stations. http://agebb.missouri.edu/weather/ stations/index.htm.

Anderson, S.H., C.J. Gantzer, and J.R. Brown. 1990. Soil physical properties after 100 years of continuous cultivation. Journal of Soil and Water Conservation 45(1):117-121.

Baer, J.U., and S.H. Anderson. 1997. Landscape effects on desiccation cracking in an Aqualf. Soil Science Society of America Journal 61(5):1497-1502.

Bennett, H.H. 1939. Soil Conservation. New York: McGraw-Hill.

Berry, J.K., J.A. Delgado, R. Khosla, and FJ. Pierce. 2003. Precision conservation for environmental sustainability. Journal of Soil and Water Conservation 58(6):332-339.

Blanchard, P.E., and W.W. Donald. 1997. Herbicide contamination of groundwater beneath claypan soils in North-Central Missouri. Journal of Environmental Quality 26(6):1612-1621.

Blanchard, P.E., and R.N. Lerch. 2000. Watershed vulnerability to losses of agricultural chemicals: Interactions of chemistry, hydrology, and land-use. Environmental Science and Technology 34(16):3315-3322.

Blanco-Canqui, H., C.J. Gantzer, S.H. Anderson, E.E. Alberts, and F. Ghidey. 2002. Saturated hydraulic conductivity and its impact on simulated runoff for claypan soils. Soil Science Society of America Journal 66(5):1596-1602.

Blevins, D.W., D.H. Wilkerson, B.P. Kelly, and S.R. Silva. 1996. Movement of nitrate fertilizer to glacial till and runoff from a claypan soil. Journal of Environmental Quality 25(3):584-593.

Bockhold, A.R., A.L. Thompson, C. Baffaut, and E.J. Sadler. 2006. Evaluating BMP's in a claypan watershed. ASABE Paper No. 062114, St. Joseph, MI: American Society of Agricultural and Biological Engineers.

Bratton, S.T., and W.O. Smith. 1928. Historical geography of Salt River Community, Audrain County, MO. Missouri Historical Review 23(12):91-98.

Buyanovsky, G.A., R.J. Kremer,A.M. Gajda, and H.V. Kazemi. 1995. Effect of corn plants and rhizosphere populations on pesticide degradation. Bulletin of Environmental Contamination and Toxicology 55(5):689-696.

Craig, M.E. 2001. The NASS cropland data layer program. In Proceedings of the Third International Conference on Geospatial Information in Agriculture and Forestry (CDROM). Ann Arbor, MI:Veridian.

Di Luzio, M., J.G. Arnold, and R. Srinivasan. 2004 Integration of SSURGO maps and soil parameters within a GIS-NPS model system. Journal of Soil and Water Conservation 59(4):123-133. 
Donald, W.W., A.T. Hjelmfelt, and E.E. Alberts. 1998 Herbicide distribution and variability across Goodwater Creek watershed in north central Missouri. Journal of Environmental Quality 27(5):999-1009.

Drummond, S.T., K.A. Sudduth, A. Joshi, S.J. Birrell, and N.R. Kitchen. 2003. Statistical and neural methods for site-specific yield prediction. Transactions of the ASAE 46(1):5-14.

Fenneman, N.M., and D.W.Johnson. 1946. Physical Divisions of the United States. Reston,VA: US Geological Survey. Scale 1:7,000,000

Gantzer, C.J., S.H. Anderson, A.L. Thompson, and J.R. Brown. 1990. Estimating soil erosion after 100 years of cropping on Sanborn Field. Journal of Soil and Water Conservation 45(6):641-644.

Gantzer, C.J., S.H.Anderson,A.L.Thompson, and J.R. Brown 1991. Evaluation of soil loss after 100 years of soil and crop management. Agronomy Journal 83(1):74-77

Ghidey, F., and E.E. Alberts. 1998. Runoff and soil losses as affected by corn and soybean tillage systems. Journal of Soil and Water Conservation 53(1):64-70.

Ghidey, F., P.E. Blanchard, R.N. Lerch, N.R. Kitchen, E.E. Alberts, and E.J. Sadler. 2005a. Measurement and simulation of herbicide transport from the corn phase of three cropping systems. Journal of Soil and Water Conservation 60(5):260-273.

Ghidey, F., E.J. Sadler, R.N. Lerch, and C. Baffaut. 2005b. Simulating hydrology and water quality of a claypan soil watershed. ASAE Paper No. 052084. St. Joseph, Michigan:American Society of Agricultural Engineers.

Ghidey, F., E.J. Sadler, R.N. Lerch, and C. Baffaut. 2007. Scaling up the SWAT model from Goodwater Creek Experimental Watershed to the Long Branch Watershed. ASABE Paper No. 072043. St. Joseph, Michigan: American Society of Agricultural and Biological Engineers.

Henning, D. 1975. Cannon Reservoir Archaeological Project Report. Lincoln, NE: University of Nebraska Press.

Howard, G.R. 1980. Ralls County Missouri. Marceline, MO: Walsworth Press.

Jamison, V.C., D.D. Smith, and J.F. Thornton. 1968. Soil and water research on a claypan soil. USDA Technical Bulletin. 1379. Washington, DC: US Government Printing Office.

Jang, G., K.A. Sudduth, E.J. Sadler, and R.N. Lerch. 2005 Watershed-scale crop type delineation using seasonal trends in remote sensing-derived vegetation indices. In 2005 Annual Meeting Abstracts (CDROM) Madison, WI: American Society of Agronomy, Crop Science Society of America, and Soil Science Society of America.

Jiang, P., S.H. Anderson, N.R. Kitchen, E.J. Sadler, and K.A. Sudduth. 2007. Landscape and conservation management effects on hydraulic properties of a claypan-soil toposequence. Soil Science Society of America Journal 71(3):803-811.

Jung, W.K. 2005. Claypan Soil Quality Related to Agricultural Management and Landscape Variability. PhD Dissertation. University of Missouri, Columbia, MO.

Jung,W.K., N.R. Kitchen, K.A. Sudduth, R.J. Kremer, and P.P. Motavalli. 2005. Claypan soil quality indicators can be characterized using apparent soil electrical conductivity. Soil Science Society of America Journal 69(3):883-892.

Jung, W.K., N.R. Kitchen, S.H. Anderson, and E.J. Sadler. 2007. Crop management effects on water infiltration for claypan soils. Journal of Soil and Water Conservation 62(1):55-63

Karlen, D.L., M.J. Mausbach, J.W. Doran, R.G. Cline, R.F Harris, and G.E. Schuman. 1997. Soil quality:A concept, definition, and framework for evaluation. Soil Science Society of America Journal 61(1):4-10.

Kitchen, N.R., P.E. Blanchard, D.F. Hughes, and R.N. Lerch. 1997. Impact of historical and current farming systems on groundwater nitrate in northern Missouri. Journal of Soil and Water Conservation 52(4):272-277.

Kitchen, N.R., D.F. Hughes, W.W. Donald, and E.E. Alberts. 1998. Agrichemical movement in the root-zone of claypan soils: Ridge- and mulch-tillage farming systems compared. Soil and Tillage Research 48(3):179-193.

Kitchen, N.R., K.A. Sudduth, D.B. Myers, R.E. Massey, E.J Sadler, R.N. Lerch, J.W. Hummel, and H.L. Palm. 2005. Development of a conservation-oriented precision agriculture system: Crop production assessment and plan implementation. Journal of Soil and Water Conservation 60(6):421-430

Koelling-Bockhold, A.R. 2006. Modeling the Influence of Climate and Management Practices on Water Quality in Goodwater Creek Experimental Watershed. Master's thesis, University of Missouri, Columbia, MO.

Kremer, R.J., and J. Li. 2003. Developing weed-suppressive soils through improved soil quality management. Soil and Tillage Research 72(2):193-202.

Krutz, L.J., S.A. Senseman, M.C. Dozier, D.W. Hoffman, and D.P. Tierney. 2003. Infiltration and adsorption of dissolved atrazine and atrazine metabolites in buffalograss filter strips. Journal of Environmental Quality 32(6):2319-2324.

Krutz, L.J., S.A. Senseman, MC. Dozier, D.W. Hoffman, and D.P. Tierney. 2004. Infiltration and adsorption of dissolved metolachlor, metolachlor oxanilic acid, and metolachlor ethanesulfonic acid by buffalograss (Buchloe dactyloides) filter strips. Weed Science 52(1):166-171.

Krutz, L.J., R.M. Zablotowicz, K.N. Reddy, C.H. Koger, and M.A. Weaver. 2007. Enhanced degradation of atrazine under field conditions correlates with a loss of weed control in the glasshouse. Pest Management Science 63(1):23-31.

Lerch, R.N., and P.E. Blanchard. 2003. Watershed vulnerability to herbicide transport in northern Missouri and southern Iowa streams. Environmental Science and Technology 37(24):5518-5527.

Lerch, R.N., N.R. Kitchen, R.J. Kremer, W.W. Donald, E.E. Alberts, E.J. Sadler, K.A. Sudduth, and F. Ghidey. 2005. Development of a conservation-oriented precision agricultural system: Water and soil quality assessment. Journal of Soil and Water Conservation 60(6):411-421.

Lin, C.H., R.N. Lerch, H.E. Garrett, W.G. Johnson, D. Jordan, and M.F. George. 2003. The effect of five forage species on transport and transformation of atrazine and isoxaflutole (Balance) in lysimeter leachate. Journal of Environmental Quality 32(6):1992-2000.

Lin, C.H., R.N. Lerch, H.E. Garrett, C.J. Gantzer, and S.H. Anderson. 2007. Utilizing vegetative buffer strips to remove dissolved and sediment-bound atrazine, metolachlor, and glyphosate from surface water runoff. In Proceedings of the 10th North American Agroforestry Conference, Quebec City, Quebec, Canada. (CDROM)

Locke, M.A., and R.M. Zablotowicz. 2004. Pesticides in soil -benefits and limitations to soil health. In Managing Soil Quality: Challenges in Modern Agriculture, ed. P. Schjonning, S. Elmholt, and B.T. Christensen, 239-260. Oxford, UK: CAB International.

Miles, R.J., and R.D. Hammer. 1989. One hundred years of Sanborn field: Soil baseline data. In Proceedings of the Sanborn Field Centennial, Publication No. SR-415, ed. J.R. Brown, 100-108. Columbia, MO: University of Missouri.
Missouri Department of Conservation. 2004. Salt River Watershed: Inventory and Assessment. http://www.mdc. mo.gov/fish/watershed/salt/.

National Academy of Sciences. 1986. Soil Conservation: Assessing the National Resources Inventory. Vol. 1. Washington, DC: National Academy Press.

Nortcliff, S. 2002. Standardisation of soil quality attributes. Agricultural Ecosystems and Environment 88(2):161-168

O’Brien, M.J. 1984. Grassland, forest, and historical settlement: An analysis of dynamics in Northeast Missouri. Lincoln, NE: University of Nebraska Press.

Peschel, J.M., P.K. Haan, and R.E. Lacey. 2006. Influences in soil dataset resolution on hydrologic modeling. Journal of the American Water Resources Association 42(5):1371-1389.

Power, J.F., R. Wiese, and D. Flowerday. 2001. Managing farming systems for nitrate control: A research review from Management Systems Evaluation Areas. Journal of Environmental Quality 30(6):1866-1880.

Ritchie,J.C., P.V.Zimba, and J.H.Everitt. 2003. Remote sensing techniques to assess water quality. Photogrammetric Engineering and Remote Sensing 69(6):695-704.

Sadler, E.J., C. Baffaut, F. Ghidey, R.N. Lerch, and E.E. Alberts. 2005. SWAT model evaluations for simulating stream flow and water quality in the Goodwater Creek Watershed.Abstract. ASA-CSSA-SSSA Annual Meeting, Salt Lake City, UT.

Sadler, E.J., R.N. Lerch, E.E. Alberts, and T.L. Oster. 2006a. Long-Term Hydrologic Database: Goodwater Creek, Missouri. In Proceedings of the 2nd Interagency Conference on Research in the Watersheds. Otto, NC: Coweeta Hydrologic Laboratory.

Sadler, E.J., C. Baffaut, R.N. Lerch, S.H. Anderson, F. Ghidey, and E.E. Alberts. 2006b. Calibration and validation of the SWAT model in Goodwater Creek Watershed. ASABE Paper No. 062235. St. Joseph, Michigan: American Society of Agricultural and Biological Engineers.

Seaber, P.R., F.P. Kapinos, and G.L. Knapp. 1987. Hydrologic Unit Maps. US Geological Survey Water-Supply Paper 2294. Reston,VA: US Geological Survey.

Shafique, N.A., F. Fulk, B.C. Autrey, and J. Flotemersch. 2003 Hyperspectral remote sensing of water quality parameters for large rivers in the Ohio River basin. In Proc. First Interagency Conf. on Research in the Watersheds, ed. K.G. Renard, S.A. McElroy, W.J. Gburek, H.E. Canfield, and R.L. Scott, 216-221. Washington DC: USDA Agricultural Research Service.

Shanahan, J.F., K. Holland, J.S. Schepers, D.D. Francis, M.R. Schlemmer, and R. Caldwell. 2003. Use of crop reflectance sensors to assess corn leaf chlorophyll content. In Digital Imaging and Spectral Techniques: Applications to Precision Agriculture and Crop Physiology, 129-144. ASA Special Pub. 66. Madison, WI: American Society of Agronomy, Crop Science Society of America, and Soil Science Society of America.

Soil Science Society of America. 2001. Glossary of Soil Science Terms 2001 Edition. Madison, WI: Soil Science Society of America.

Staben, M.L., D.R. Bezdicek, J.L. Smith, and MF. Fauci. 1997. Assessment of soil quality in conservation reserve program and wheat-fallow soils. Soil Science Society of America Journal 61(1):124-130.

Stanley, L. 1999. A Characterization of Bacterial Populations from Two Sites. PhD dissertation. University of Missouri.

Sudduth, K.A., N.R. Kitchen, G.A. Bollero, D.G. Bullock, and W.J. Wiebold. 2003. Comparison of electromagnetic induction and direct sensing of soil electrical conductivity. Agronomy Journal 95(3):472-482. 
Sudduth, K.A., G. Jang, R.N. Lerch, and E.J. Sadler. 2006. Hyperspectral reflectance sensing of reservoir water quality. In Proceedings of the 20th Biennial Workshop on Aerial Photography, Videography, and High Resolution Digital Imagery for Resource Assessment (CD ROM). Bethesda, MD: American Society for Photogrammetry and Remote Sensing.

Troeh, F.R., J.A. Hobbs, and R.L. Donahue. 1980. Soil and water conservation for productivity and environmental protection. Englewood Cliffs, NJ: Prentice-Hall Inc.

US Army Corps of Engineers. 1975. Clarence Cannon Dam and Reservoir: Final Environmental Statement. St. Louis, MO: US Army Corps of Engineers.

USDA NRCS (Natural Resources Conservation Service). 2000a. Conservation Buffers to Reduce Pesticide Losses. Washington, DC: USDA Natural Resources Conservation Service.

USDA NRCS. 2000b. Missouri National Resources Inventory Soil Erosion Tables. Columbia, MO: USDA Natural Resources Conservation Service. http://www. mo.nrcs.usda.gov/technical/nri/erosionindex.html.

USDA NRCS. 2004 Windows Pesticide Screening Tool. Portland, OR: National Water and Climate Center, USDA Natural Resources Conservation Service.

USDA NRCS. 2005a. National Collection of Soil Survey Geographic Data: SSURGO Version 2.1. Lincoln, NE: National Soil Survey Center.

USDA NRCS. 2005b. National Soil Survey Handbook, Title 430-VI. Lincoln, NE: USDA Natural Resources Conservation Service. http://soils.usda. gov/technical/handbook/.

USDA NRCS. 2006. Land Resource Regions and Major Land Resource Areas of the United States, the Caribbean, and the Pacific Basin. Agricultural Handbook 296. Washington, DC: US Government Printing Office.

Ward, A.D., J.L. Hatfield, J.A. Lamb, E.E. Alberts, T.J. Logan, and J.L. Anderson. 1994. The management systems evaluation areas program: Tillage and water quality research. Soil and Tillage Research 30(1):49-74.

Wang, X., and A.M. Melesse. 2006. Effects of STATSGO and SSURGO as Inputs on SWAT Model's Snowmelt Simulation. Journal of the American Water Resources Association 42(5):1217-1236.

Woodruff, C.M. 1987. Pioneering erosion research that paid. Journal of Soil and Water Conservation 42(2):91-92. 